

U T S

e PRES S
Public History Review

Vol. 25, 2020
(C) 2020 by the author(s). This

is an Open Access article

distributed under the terms

of the Creative Commons

Attribution 4.0 International

(CC BY 4.0) License (https://

creativecommons.org/licenses/

by/4.0/], allowing third parties

to copy and redistribute the

material in any medium

or format and to remix,

transform, and build upon the

material for any purpose, even

commercially, provided the

original work is properly cited

and states its license.

Citation: Donnelly, D. J. and Shaw, E. L. 2020. Docudrama

as 'Histotainment'

Repackaging Family History in the Digital Age. Public History Review, 25, 1-14.

ISSN 1833-4989 | Published by UTS ePRESS | https://epress. lib.uts.edu.au/journals/index. php/phrj

\section{Docudrama as 'Histotainment': Repackaging Family History in the Digital Age}

\author{
Debra J. Donnelly and Emma L. Shaw
}

With the proliferation of digital technologies and the resulting democratisation of historical records the past is more accessible to consumers than ever before. This has propelled the rapid evolution of what is now the multi-billion-dollar family history industry. Proclaimed an 'epidemic', ${ }^{1}$ genealogy and family history research has become 'the fastest growing hobby in both Britain and America as well as mainland Europe, Canada and Australia.'. Indeed, after pornography, family history is the second most accessed website genre currently accessed daily across the globe. ${ }^{3}$ Accompanying internet interest in family history research, there has been an explosion of family history themed media productions such as documentaries, docudramas and reality TV shows.

Historical docudramas that focus on family history are a contemporary television phenomenon. These productions are often investigative and use simulation and location to explore family and social history repackaged for public consumption. This research investigates the mechanisms at work in family history docudramas which it situates as public history for a didactic as well as an entertainment purpose. The analysis takes a case study approach and compares two recent and popular docudramas, the Australian versions of Who Do You Think You Are? and Back in Time for Dinner. These texts were chosen as the latest contribution to what has been a long line of this type of docudrama televised in Australia and because they were produced and released within a few months of each other. They were analysed incorporating a content analysis approach and subsequently utilising Peter Seixas' Historical Thinking Concepts. ${ }^{4}$ The findings are represented in the form of a model for the repackaging of history in docudrama.

\section{Popular Culture, Film and History}

The family history industry can be positioned as a manifestation of popular culture in that it has broad mass appeal, is widely accessible for most of society, it is constantly changing and has a reliance on mass communication technologies. According to Paul Ashton and Paula Hamilton, television and the internet have become important in 'mediating between the personal experience and the public memory of events and also genders and generations'. ${ }^{5}$ Their Australians and their Pasts survey showed that watching television and documentaries were the most preferred historical activities of a cross-section of Australian citizens. 
U T S

e PRES S

This 'visually inundated world' with the prevalence and pervasiveness of the image, sees historical films connecting to societal knowledge, popular culture and the world beyond. The population, it is argued, now have greater access to popular culture, including film, than ever before with the popularity of theatre-going, easy access to DVDs and downloading from the Internet. Last year it was estimated that adults spent eleven hour per day on media consumption with at least six of those hours being devoted to watching TV and video. Younger viewers reported preferring their media consumption on digital platforms such as apps/web via smartphones and tablets. ${ }^{7}$

Historical films' engagement with the past is different to that of scholarly research. When weighing up their respective advantages, it is more likely that the scholarly research would align more closely with the evidence, but that films reach a wider audience and can present strong visual representations. Postmodernists argue that every history, written or otherwise, is above all a representation and as such cannot be an adequate account of the past. Robert A. Rosenstone argues that written research and film are both legitimate forms of historical knowledge: 'it is time for historians to accept the mainstream historical film as a new form of history... Movies create a world of history that stands adjacent to written and oral history'. ${ }^{8}$

Robert Toplin points out that written history has time to speculate and suggest alternative interpretations while filmmakers must present a complete and coherent account on screen or risk losing their audience. Toplin sees the appeal of film as having an intellectual and affective dimension. He contends that film 'pulls audience interest toward a study of the subject... Movies give audiences a feeling for life in a distant time and place. ${ }^{9}$ Historical docudramas combine evidence and narrative with dramatic and affective elements to produce a representation of the past for public consumption.

\section{Docudramas as Public History}

An historical docudrama, also known as non-fiction drama, is a performance of the past designed for contemporary audiences that combines elements of drama with the documentary form. There is an obvious tension in the hybridity of the term docudrama. 'Drama' suggests fiction and emotion. 'Documentary' has connotations of objective reality, often with a didactic purpose. Like other forms of historical films, the docudrama 'regularly structures material into the conventions of drama, with a story that begins with certain problems, questions, and/or characters at the outset, develops their complications over time, and resolves them by the end of the film. ${ }^{10}$

Compared to historical feature films, docudramas tend to adhere more closely to an evidentiary record and may not sacrifice history for entertainment value. Docudramas can be effective vehicles for the examination of social structures and codes of a specific time and culture, and so highlighting similarities and contrast to present-day circumstances, values and expectations. Commonly emphasising biography, these films set micro-narratives of individuals or groups against the backdrops of macro-historical events. Docudramas employ a variety of narrative and literary techniques to explore the past such as dramatic irony and tension. ${ }^{11}$ As they adopt conventions from drama, docudrama draw on performance modes from fictional television forms and invites audiences to use their knowledge of codes used in fictional filmic narratives. These facilitate presentations of the historical narratives that are engaging, memorable and elicit empathetic responses. ${ }^{12}$ The research has introduced the term 'histotainment' for this fusing of history and entertainment. 
The term historical docudrama covers a wide continuum of productions from films claiming to be 'based on true events' and so presenting a re-creation of the past with sets and actors to works whose claims of historical veracity are supported by explicit use of evidence and the omnipresent narrator. This article uses two examples of the later style of docudrama in which the journey from the present to the past is explicitly told and where evidence, location and recreation are melded to reveal and perform the past in and for the present.

\section{Backgrounding the Objects of Study}

By 2007 Who Do You Think You Are?, originally airing in Britain in 2004, had 'become the second most popular non-fiction program ever shown on British television. ${ }^{13}$ Mirroring Jose van Dijck's term of 'mediated memories', the producers used family history research for 'creative acts of cultural production and collection through which people make sense of their own lives and their connection to the lives of others'. ${ }^{14}$ The Australian version of Who Do You Think You Are? is currently in its tenth season, ${ }^{15}$ which speaks to its popularity and its connection in the Australian context.

Who Do You Think You Are? is meticulous and transparent in its use of sources and is publicly pedagogic in that it demonstrates how the viewers can undertake their own genealogical journeys. Using a celebrity avatar, the program fuses genealogical processes to the simultaneous exploration of issues of social morality, cultural and institutional change, immigration and class mobility. ${ }^{16}$ There is a clear documentary narrative deployed, with voiceovers explain the relevance and importance of key findings and providing the audience with the historical context and information as it is disclosed to the celebrity avatar. ${ }^{17}$ The program is at once biographical and autobiographical. ${ }^{18}$ And the metaphor of the journey frames the program: the journey through time; the journey through class and social constraints; the geospatial journey; and indeed the journey through history itself.

Back in Time for Dinner was released in Australia in 2018. An Australian Broadcasting Corporation production, this program was a six-part series foray into a docudrama format. It featured a conglomerate of historical re-enactment, nostalgia, artefacts and anachronism to trace an Australian family from 1950s to the present and beyond. As with other docudramas, the Australian Back in Time for Dinner was modelled on a British original and its spin-offs. ${ }^{19}$ The unashamedly contrived series is built on the conflict experienced by the Ferrones, a 'contemporary everyday Australian family' caught in a time shift that sees them cooking and eating unfamiliar food and being subject, and in many cases constrained by, the mores of the decade of the week. The narrator, commentator and master of ceremonies of the series is the well-known Australian presenter, Annabel Crabb, who has her own retro vibe. The programs are episodic encounters and collisions between history and the present and feature the use of historical artefacts such as archival film, classic cars, decade appropriate ephemera and architectural time-shifted kitchen and living spaces.

\section{Research Design}

Our research utilises a content analysis approach as a qualitative methodology for analysing docudramas as histotainment and how they repackage the past in the present. Following Figueroa's ${ }^{20}$ approach to the analysis of audio-visual texts, the two-phased analysis involved constructionist grounded theory procedures with an initial focus on the documentary as a 'whole' and a subsequent analysis using an historical understanding framework. ${ }^{21}$ This method allowed for the texts to be analysed for meta-historical skills and concepts - the juncture 
U T S

e PRES S

between the past and the present - as well as elements related to the theatrical form of the docudrama. Emergent perspectives and ideas were identified, coding nodes were developed in NVivo data analysis software and thematic trees established.

An analytical framework was developed from the data coding and four thematic domains were identified: History Disciplinary Practices; Metahistorical Concepts; Past/Present (dis) Juncture; and Popular Culture and Theatre (see Figure 1). To further examine and compare the attributes in each domain an analytic rubric was devised (see Table 1). This scored each attribute from 0-5 based on coding frequencies. The rubric scores allowed for comparison of attributes and domains in and across both docudramas (see Table 2). This analytical procedure sought to answer the research questions: how do these docudramas repackage history for public consumption and what factors contribute to the impact of these narratives?

\section{Findings and Discussion}

\section{FINDINGS AND DISCUSSION}
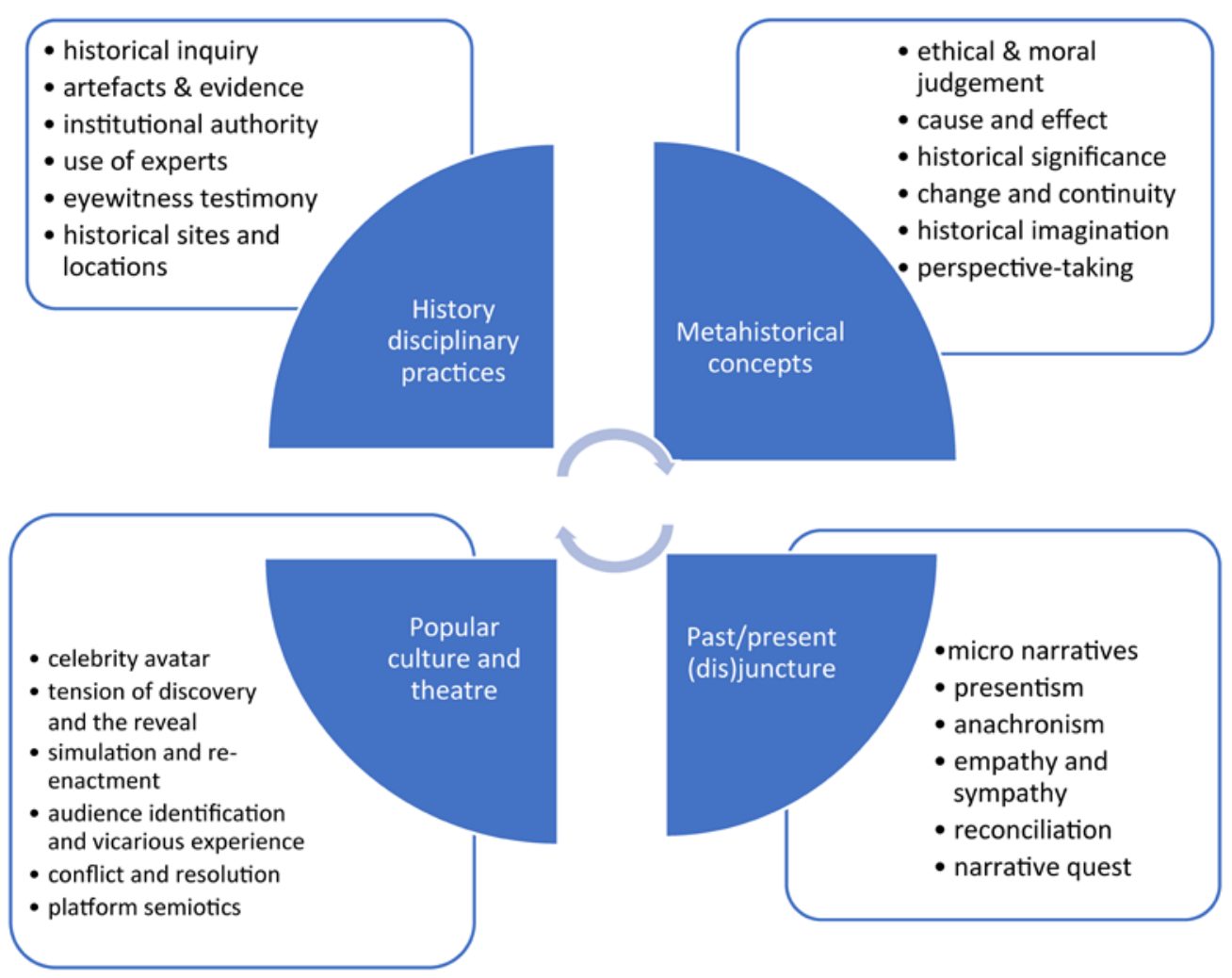

Figure 1 Histotainment: Repackaging the Past in the Digital Age

Table $1 \quad$ Quantified Data Rubric

\begin{tabular}{|l|l|l|l|l|l|l|}
\hline $\begin{array}{l}\text { Coding } \\
\text { frequency }\end{array}$ & $\begin{array}{l}\text { Not } \\
\text { present }\end{array}$ & Minimal & $\begin{array}{l}\text { A few } \\
\text { instances }\end{array}$ & Evident & $\begin{array}{l}\text { Strongly } \\
\text { evident }\end{array}$ & $\begin{array}{l}\text { Evident } \\
\text { throughout }\end{array}$ \\
\hline $\begin{array}{l}\text { Assigned } \\
\text { Score }\end{array}$ & 0 & 1 & 2 & 3 & 4 & 5 \\
\hline
\end{tabular}


Table 2 Quantified Data Frequency for Elements and Domains

\begin{tabular}{|c|c|c|c|}
\hline Domain & Elements & $\begin{array}{l}\text { Back In Time } \\
\text { for Dinner }\end{array}$ & $\begin{array}{l}\text { Who Do You } \\
\text { Think You } \\
\text { Are? }\end{array}$ \\
\hline \multirow{6}{*}{$\begin{array}{l}\text { History Disciplinary } \\
\text { practices }\end{array}$} & Historical Inquiry & 0 & 5 \\
\hline & Artefacts and evidence & 5 & 5 \\
\hline & Institutional authority & 1 & 4 \\
\hline & Use of experts & 5 & 5 \\
\hline & Eyewitness testimony & 3 & 3 \\
\hline & $\begin{array}{l}\text { Historical sites and } \\
\text { locations }\end{array}$ & 2 & 5 \\
\hline Domain score & & 16 & 27 \\
\hline \multirow[t]{6}{*}{$\begin{array}{l}\text { Metahistorical } \\
\text { concepts }\end{array}$} & $\begin{array}{l}\text { Ethical and moral } \\
\text { judgement }\end{array}$ & 4 & 3 \\
\hline & Cause and effect & 5 & 5 \\
\hline & Historical significance & 4 & 5 \\
\hline & Change and continuity & 5 & 5 \\
\hline & Historical imagination & 4 & 3 \\
\hline & Perspective taking & 4 & 5 \\
\hline Domain score & & 26 & 26 \\
\hline \multirow{6}{*}{$\begin{array}{l}\text { Past/present (dis) } \\
\text { juncture }\end{array}$} & Micro narratives & 5 & 5 \\
\hline & Presentism & 5 & 3 \\
\hline & Anachronism & 5 & 2 \\
\hline & Empathy and sympathy & 5 & 5 \\
\hline & Reconciliation & 2 & 5 \\
\hline & Narrative quest & 3 & 5 \\
\hline Domain score & & 24 & 25 \\
\hline \multirow{6}{*}{$\begin{array}{l}\text { Popular culture and } \\
\text { theatre }\end{array}$} & Celebrity avatar & 4 & 5 \\
\hline & $\begin{array}{l}\text { Tension of discovery and the } \\
\text { reveal }\end{array}$ & 4 & 5 \\
\hline & $\begin{array}{l}\text { Simulation and re } \\
\text { enactment }\end{array}$ & 5 & 1 \\
\hline & $\begin{array}{l}\text { Audience identification and } \\
\text { vicarious experience }\end{array}$ & 5 & 3 \\
\hline & Platform semiotics & 4 & 5 \\
\hline & Conflict and resolution & 4 & 3 \\
\hline Domain score & & 26 & 22 \\
\hline
\end{tabular}


U T S

e PRES S

\section{Discussion of the Domains}

\section{HISTORY DISCIPLINARY PRACTICES IN BACK IN TIME FOR DINNER}

Back in Time for Dinner (2018) is dressed in the apparel of an historical investigation but does not present as an inquiry, hence its relatively low score of $16 / 30$ on this domain. The program assumes that the past is uncontested and knowable, so able to be set up by the production team, for the Forrone family to explore and experience. The device of an authoritative voiceover is used to carry the historical narrative giving an account of trends and changes as well as the action of the re-creative events, such as going to a Drive-in in the 1950s and the 1980s popularity of exotic take away cuisines such as Thai and Vietnamese. Archival film, such as newsreels, sets the scene and provides contextualization, such as the footage of the 1983 America's Cup win and the dismissal of the Whitlam Government in 1975. The voice-over narrative is reinforced by on-screen text that provides seemingly reliable, yet unsubstantiated statistical information, such as 'women still do more than twice of the housework in 1970s as compared to men.'

Historical documents and spaces set the scene for the action in this program and lend an authenticity to the action. The family are not seen visiting libraries or historical archive repositories. But the archives come to them. Every week the family home is morphed into a new decade and so the house re-creates the past and the family are actors in the space. The artefacts in the form of recipe books, retro kitchenallia and decade-typical architecture are used to set the scene, and as prompts to the action and tension. For example, when Carol struggles to replicate a chicken liver pineapple dip from the 1953 Better Homes, Garden New Cookbook, and uses the wringer washing machine.

The device of the visitors also propels the action with prominent people such as deportment and style entrepreneur June Dally-Watkins, Michelle Bridges from Biggest Loser fame and restaurateur and food educator, Stephanie Alexander dropping by to give their perspective on their life and times. They are eye-witnesses to the past and provide testimony as well as memory. An intriguing visitor encounter was from swimming icon and now 81-year-old Dawn Fraser. In what was a post-modern twist, the family gathered around the radio cheering Fraser on in her 1956 Melbourne Olympics win. There was real excitement as the family urged her on and cheered and congratulated her when she won, even though they all knew that the win was many years ago. The event was made even more stimulating as Fraser claimed never to have heard the race before. Her revelation of the gender and class bias that she faced in 1950s added to the triumph. Fraser claims that she was told that she would 'Never represent Australia as you are working class.'

The use of evidence lends authenticity to the action. But it is highly selective and designed to provide very general easily digestible information and targeted at the perceived entertainment value for a modern audience. There is a certain smugness that suggests the production team and actors subscribe to the notion that the present is 'better' than the past and the docudrama aims to confirm this to the contemporary audience. Such judgmental and over generalised statements are evident even in the voice-over narration as '50s cooking was a basic affair' (episode 1) and from the 1980s (episode 4): 'It wasn't enough to dress foolishly and work out. You had to be on a diet.'The underlying notion of technology and change always being positive is tedious to anyone interested in a serious consideration of the question of societal progress or decline. There is no attempt at balancing the historical record and many of 
the ideas are based on sweeping generalisations about thought and action in each decade with no concession to differences between individuals or groups.

\section{HISTORY DISCIPLINARY PRACTICES IN WHO DO YOU THINK YOU ARE?}

Unsurprisingly, the History Disciplinary Practices domain was strongly represented in the analysis of Who Do You Think You Are? The program is meticulous in its use of sources and expert testimony which lends an authority that is lacking in Back in Time for Dinner. Every episode follows the unique and personal journey of a celebrity avatar and each historical inquiry is different. Often, the celebrity in question has no real idea of what they are looking for prior to the show. But they quickly develop a focus of investigation after the first pieces of evidence about their familial pasts are revealed. Mostly, it seems as if the (selected) evidence itself initiates and drives the investigation rather than the questions and desires of the celebrity themselves. Unlike the inquiry process(es) of most family historians, the celebrities on Who Do You Think You Are? do not personally undertake the research. Rather, they are taken on a journey of discovery, as opposed to adhering to the methodological rigors of the historian for themselves.

The use of artefacts and evidence is paramount to the historical journey and a wide range of historical evidence is used from letters, wills, shipping and immigration records, to insaneasylum, workhouse and hospital records. Electoral rolls, land records, certificates - births, deaths and marriages - and census data are often referred to as are more tangible artefacts such as buildings, paintings, photographs and audio recordings. The program also uses established institutions to add gravitas to its investigation. On location, experts provide background information and contextualise the significance of the documents they reveal as they guide (and drive) the understanding of the celebrity. The experts include a range of notable Australian historians, a host of local and family historians, tour guides, specialised social historians, archivists, librarians, university lecturers, teachers and Aboriginal elders.

While eyewitness testimony is not as strong as other domain attributes (3/5) it is still evident in the data. In this context, 'eyewitness' usually took the form of someone known to the celebrity's family who could provide some personal insights into their ancestors' story. Further, personal narratives were recounted at significant historical sites and/or locations. Jennifer Byrne is told of her connections to the court of King Henry VIII through her 12xgreatgrandfather Edward Neville on location at the Tower of London.

\section{METAHISTORICAL CONCEPTS IN BACK IN TIME FOR DINNER}

Acknowledging that the scoring system is based on quantity as opposed to quality, Back in Time for Dinner scores a strong 27/30 in the Metahistorical Concept domain. Just as their 'time travelling' adventure highlights the unity of the family, the alien environment of the past creates tension as the Forrones are subjected to now outmoded value systems and role expectations. A central concern is Continuity and Change as the series is contrived as an examination of what changes and what remains constant. Flash backs to earlier episodes are used to demonstrate the changing nature of life. For example, tracing women's housework from heavy manual labour of the wringer washing machine to the robotic sweeper. Family relationships and home are stabilizing themes in the dynamic historical national and international landscapes over a time span of 60 years. The children's reaction to their parents 'romantic' wedding video and to their parents dancing around the jukebox at the drive-in is timeless and identifiable for anyone with 'embarrassing' parents. 
U T S

e PRES S
The metahistorical concept of Cause and Effect is also strongly represented in the Back in Time for Dinner. The program is an examination of the impact on the lives of a 'typical Australian family' as it is subject to historical and social forces beyond its control. The trends in food, fashions as well as technological developments and innovation are examined against a backdrop of historical, socio-cultural, political and economic factors in the second half of the twentieth century. This included post-war immigration policies and the resulting multiculturalism in Australian society and the food evolution from primarily British fare to encompass a wide variety of international cuisines as well as social change in response to changing work patterns.

The reactions of the family to their encounters with the past and in their video diaries as well as the perspectives added by the visitors provide a range of perspectives on history and the re-created historical experiences, albeit mostly from a white middle-class perspective. For example, on the issue of no parental supervision after school, Olivia's attitude stands in sharp contrast to her mother's. Carol feels guilty and neglectful of her motherly duties while Olivia explains: 'I enjoyed being a latch key kid... we could do whatever we wanted and eat lollies, we don't usually do that.'

Ethical and moral judgements abound, often undercut by inherent presentism of the program construction. For example, Carol is unable to enter into the past lives of women and is constantly judging the experience by the standards of her own time. In her view, all women working in the home were unhappy and waiting to be released from the servitude. She is distressed and lonely, with no thought beyond the experiment of the Back in Time for Dinner format to consider such things as the support of community and the differing expectations and aspirations of other times. In the1950s, Carol is the modern professional woman caught in an unfamiliar and unappealing role of homemaker: '[You have] no time for yourself, how any woman would find this fulfilling?' A strong example of ethical and moral judgement in play can be seen in the 2000s episode when Carol and Peter grapple with the human tragedy of the Stolen Generations as they watch the Kevin Rudd giving the 2008 Apology to Australia's Indigenous Peoples. Carol identifying with the separated families says: 'I just can't imagine not knowing... you wouldn't even know if your child as alive... It really hit me hard... I can't even imagine how those women went on. This decade was a very emotional experience for me personally.'

The historical significance is engaged at global, national and personal levels in Back in Time for Dinner. Major historic events are presented and with commentary on their impact. For example, the family and Annabel Crab watch the Fall of the Berlin Wall on TV and Annabel explains: 'This was tearing down a major symbol of the Cold War' and '[It is] Impossible to underestimate what a celebratory thing this was to watch the wall coming down.' Post-war immigration and the changes it wrought is a strong theme in this program, primarily due to the focus on food culture. For Peter, this is a story of the nation and of his immediate family. His parents were Italian immigrants and his family's journey is traced with the help of shipping records and family photos. The experience causes Peter to muse on the nature of history, 'Everything has come in waves and circles... revolution of backwards and forwards.'

\section{METAHISTORICAL CONCEPTS IN WHO DO YOU THINK YOU ARE?}

Metahistorical Concepts scored also strongly in the Domain score (26/30). Yet this was not a result of the celebrities understanding, or even having a familiarity, with these concepts prior to their familial investigations. It is important to note that the visibility and utilisation of the 
concepts was only possible through the guidance of the ever-present experts. Considering the concept of Perspective-taking the celebrity was able to better understand the actions and motivations of their ancestor(s) when familial information and/or narratives were contextualised by the expert within the time-period in question. Likewise, the concept of Historical Significance was understood when the expert explicitly informed the celebrity of the importance of the document/ event/narrative. Cause and Effect were better understood by most celebrities because they could see that events in the past were impactful on the present. Change and Continuity was also strong. But most celebrities demonstrated an understanding of this concept through a perceived inheritance of personal character traits.

Ethical and moral judgement was evident. While ancestral transgressions were often initially despised by the celebrity, their views ultimately shifted with additional information or context. For example, Kerry-Anne Kennerley found her grandmother's abandonment of her mother at age twelve abhorrent. She admitted that she felt she was more affected by it than her mother but scathingly questioned: 'what sort of woman just ships off her kids to be a glorified babysitter?'. She subsequently finds out that her mother was sent away as the family were impoverished and could not look after her properly. After this revelation she said: 'it makes you realise you should never be judgemental about people'. Rodger Corser was disapproving of his 5xgreat-grandfather who abandoned his family numerous times, yet concludes the episode aligning his ancestor to a well-established Australian trope of triumph over adversary: 'Risen from a convict and a deserter of families to the rank of gentleman. It certainly is an interesting story'.

There is also a lack of ethical and moral judgement in this attribute. Scott Cam enthusiastically claims an ancestor who was 'a risk taker and an adventurer... just the sort of bloke I was hoping to find'. Jennifer Byrne, upon finding out her ancestor was the mistress of King Edward III and they had four illegitimate children delights in asking: 'So now we have scandal as well as power? Excellent! Excellent!'. She reflects upon the revelation of scant evidence: 'I love the fact that Lady Joan has leapt out of history for me. It's been really lovely to realise that there's this ancestor that is everything you would want. She was strong, she fought for her family - not just her daughters, but her daughters-in-law. That's a good proto feminist. I love that. I'm very proud of her'. One cannot help but wonder how many female ancestors were ignored in favour of Lady Joan?

\section{PAST/PRESENT (DIS)JUNCTURE IN BACK IN TIME FOR DINNER}

Back in Time for Dinner scores high (24/30) in the Past/Present (dis)Juncture domain. The program creates an historical microcosm in a suburban house set against the grand narratives of global and national history, focusing on the micro-narratives of social history. The series uses anachronism and presentism as primary drivers, with the family constantly feeling out of place and with audience engagement hinging on the family finding the past uncomfortable. There are attempts to reconcile the past, present and future in this series. It is noticeable, if not surprising, that the closer the family comes to the present the less anxious they feel. As the older daughter, Sienna, says as she is handed a recognizable mobile phone: 'I am beginning to feel like my normal self.'

The last episode attempts to complete the family's journey through time by making predictions about life in the future by taking already existing discoveries to their logical conclusion. At the end of the series, there is an attempt to resolve the journey for the family. As the narrator explains: 'You spent the last six weeks working back yourself to the future 
U T S

e PRES S

where you felt comfortable and now we are going to make you quiet uncomfortable again by parachuting you into something quiet strange, the future.' In this way the series reconciles the journey from the 1950s to the present and, following the themes of food, family and social change, looks to the future.

There are elements of a quest. The quest to find meaning in change and to come to a deeper understanding of the meaning of history for the present. At the end of the series Annabel asked the son, Julian, a self-confessed history buff, to reflect on his time-travelling experience. 'Well when you study history, you tend to study all the... great people who did stuff - but when you travel back there is a lot more seeing history through the eyes of your average person. It is sort of interesting cause it is a different perspective.' This is a major objective of the program to bring the macro and micro into focus simultaneously.

\section{PAST/PRESENT (DIS)JUNCTURE IN WHO DO YOU THINK YOU ARE?}

The juncture between the past and the present is the core of the program scoring a high 25/30. The premise of each episode is framed around the narrative quest, as the celebrity (and by default, the audience) is taken on an emotional journey through their ancestral past. Such quests traverse vast swathes of historical time, with some reaching back as far as the fifteenth century. Always present is the seeking of the story, as ancestral narratives are pursued to flesh out the, at times scant, evidence. Often the experts revealing the evidence provide enough historical context to enable the celebrity to jointly-construct the family narrative.

The confluence between micro-narratives and broader historical accounts were common. In Bowraville, Casey Donnovan's family story was connected to the Freedom Rides. Kerry-Anne Kennerley uncovered links to the English whaling industry. Jennifer Byrne's long-lost ancestry placed them at the Tudor court. And Dr Karl's family were victims of the Holocaust. Rodger Corser found convicts and Irish orphans. More broadly, all episodes showed strong links to wider historical themes such as immigration, emigration, social class stratification, loss, trauma, triumph and sacrifice. It was often through the process of overcoming the disjuncture between their familial experiences in the present, and their ancestral experiences in the past, that the celebrities were able to contextualise unsettling or troubling familial information which led to a reconciliatory process.

The notion of presentism, whereby the people of the past are judged according to twentyfirst-century values, is evident, but not strong in the data, as the celebrities always had an expert to provide context to the narrative. If a celebrity started the program with preconceived judgements about an ancestor, these were usually rectified by the expert's contextualised evidence. Anachronism too was evident but not strong. Usually, anachronism was seen in the utterances of the celebrity in reaction to new-found familial evidence, and not through the production of the program itself.

\section{POPULAR CULTURE AND THEATRE IN BACK IN TIME FOR DINNER}

As a historical simulation, Back in Time for Dinner draws strongly on The Popular Culture and Theatre domain (26/30) and uses familiar film semiotics to create meaning and signal to the viewers that costume, technology and architecture will be important constants. The series constructs the physical and psychological geography of the past and sets out to have the Forrones re-enact 'out of time' experiences as entertainment. Every episode there is a reveal of the new decade as imaged in the re-constructed and decorated house and signaled by the golden key and the unlocking of the front door. The first segment of each episode is a journey 
U T S

e P R E S S of discovery for the family and the viewers as they explore the house's evolution. Segments like the Drive-In in the 1950s and the Video Arcades of the 1990s appeal to nostalgia for the recent past and provide a break from the domestic set of the family home.

The series uses a consistent structure that turns on the 'reveal' and 'discovery' and emotive reaction to create tension and dramatic irony. As the new decade takes over the interior of their house, the Ferrones' reactions to their new décor and demands of the new decade are a vital part of the drama. The distance between past and present is intentionally extended and exaggerated as the family experiments in their time capsule. For example, the choice of tripe as the first meal that Carol has to prepare for the family is designed to create maximum distress for them, even bringing Olivia to tears. Similarly, the presentation and eating of insects as a future food (episode 7) is designed for maximum disgust. Annabel Crabb has a retro vibe that suits her role as facilitator and is a well-known celebrity for the $\mathrm{ABC}$ docudrama watching audience.

The different family members resonate across a wide demographic, enhancing the vicarious experiences for the viewers. With each episode, the viewers are drawn into the family characters and their interactions with the past. This is enhanced by video diary pieces to camera during which individual family members give their version and opinion of events. Carol's genuine reaction to the Food Bank and Stolen Generations (in episode 6) and the visit of Peter's mother (episode 2) to the set are instances of an affective dimension that arise from the family's conformation of the past. Viewers can readily identify with Carol's fear for her children who have to walk rather than be driven and are without mobile phones and the parent's time bending experience of going out on a date in the 1990s. 'I felt like I was 18 and dating him again,' Carol comments as the pair drive around in the Ford Capri. The viewers come to know the family and can identify with their attitudes, dilemmas and struggles. It is history as entertainment and although it is historical in nature, entertaining viewers is a primary driver.

\section{POPULAR CULTURE AND THEATRE IN WHO DO YOU THINK YOU ARE?}

Who Do You Think You Are? is a manifestation of popular culture and theatre, yet scored a comparatively low 20/30 on the Domain score. While the journeys of the celebrities vary, certain formulaic traits are observable in the platform semiotics. For example, the tension of discovery and reveal is identical in every episode. The celebrities are 'drip-fed' information from the expert(s), and the camera pans in to capture their reactions. Documents to support the narrative are revealed singularly and often at locations of importance as the expert provides historical context. For example, Dr Karl Kruszelnicki is told a harrowing account of Jewish elders and children murdered during the Holocaust in front of the train cars used to transport them to their demise. It is then revealed that his own grandmother was among the elderly who were also killed. 'I'm feeling like I've been through an emotional wringer. I had no idea the being in the place where my grandmother and mother were processed, with the express goal of killing them... just came up on me'. This resulted in an extremely complex and multi-layered affective reaction for both the Dr Kruszelnicki and the audience.

There is a clear affective intent, for both the celebrity and the audience. Through tales of tribulations and triumphs, the celebrities are indeed put through 'an emotional wringer'. Simultaneously, the audience at home reacts and identifies with the celebrity through the notion of vicarious experience. Yet this does not occur from the documents or stories alone. These emotional reactions of the program are undeniable but they are nonetheless staged. 
U T S

e PRES S
Background music and the location shots where the celebrities are seen processing their familial news ensures we at home are told how to react to the tension of discovery and reveal of the celebrities.

The idea of discovery is also contrived. As each episode commences, the celebrity either muses about what they hope to discover or the narrator tells us about the life of the celebrity. In every instance, these hopeful musing are 'discovered' in the journey and so set the theme of the episode. Personal character traits are usually emphasised and links are often made to ancestors who are seen to share the same. Scott Cam, positioned as someone fond of water in the opening scenes of the program, made constant links to it on his journey. Also portrayed as 'hard-working', he draws constant links to this positive characteristic among his ancestors. Of his female ancestors coming to Australia, he says they 'must have been strong women to survive...classic Cam women. Very strong and hardworking'. Of particular note here is the narrative of their sea journey. No mention of their work experiences was made.

For Kerry-Anne Kennerley, determination and 'sheer grit' are the themes of the episode, as is a strong focus on her marriage, touted by the narrator as one of the 'greatest love stories'. Throughout the journey we find ancestors who display 'grit'. Her familial journey is brought full-circle by her rather tenuous claim that her previously-unknown ancestor had 'deep and meaningful love affair with her husband. I understand that because of my husband'. For Casey Donnovan, 'strength and determination' is emphasised, as is a fear that she is 'not Aboriginal enough'. These fears were soon unfounded as connections with her determined and strong Aboriginal family were made through documents, music and personally visiting locations of ancestral significance. Through tears, she says: 'It makes me feel like I belong'. In most episodes the questions raised by the journey are resolved.

However, the attribute of conflict and resolution is not as strongly represented in the data as others in this domain. Conflict here refers to the inner conflict of the celebrity as they struggle to understand and accept any familial narratives they find unsavoury. Usually the conflict is only resolved after the expert who revealed the narrative contextualises the information for them. Kerry-Anne Kennerley travels to Hull in England on a quest to prove/ disprove a paternal family rumour of a ship's captain. She is horrified and disappointed to discover he commanded a whaling ship. 'I'm not really into whaling... I like the whales'. After the expert then informs her how crucial whaling was for the society at the time she is visibly more accepting. Her internal conflict, through the historical context provided by the expert, is resolved. She says: 'I never expected to be related to a whaler... but you can't judge another time in history by the standards we have today'.

\section{Conclusion}

This article has explored how history is repackaged for public consumption through an analysis of two contemporary family history docudramas. It identifies and quantifies the domains and their individual attributes which explain the appeal and impact of historically-based docudramas and introduces the term 'histotainment' to describe the blending of history and entertainment. The Australian TV versions of Back in Time for Dinner (2018) and Who Do You Think You Are? (2019) were selected for analysis as recent examples of popular family explorations. This paper proposes a conceptual model, entitled Histotainment: Repackaging the past in the digital age, which represents the melding of history and drama to produce creative works with entertainment as well as didactic intent. 
The four domains of the model - History Disciplinary Practices, Metahistorical Concepts, Past/Present (dis)Juncture, and Popular Culture and Theatre - were all represented in the data to varying degrees. The strongest result for both television programs was in the Metahistorical Concept domain. This is indicates that they deal effectively with 'big picture' notions of how history is perceived and understood by the present. This underscores the significant role of infotainment media in making the past accessible and presenting the public with sophisticated notions of the nature of history. This finding also has broad implications for more formal educative settings as it highlights the uses of docudramas for teaching and learning about historical concepts and understandings.

The Past/Present (dis)Juncture domain was also strongly represented in the data for Back in Time for Dinner (2018) and Who Do You Think You Are? (2019). The attributes of this domain highlight the tensions inherent in bridging time and space and the dynamic nature human history. These programs explore the connections that pull us back in time, and highlights the distance caused by technological shifts and changing values. The strong emotional underpinnings that develop between, and connect, the viewers and the programs' avatars underscore the (re)accessibility of the past to individuals who may not be interested in 'traditional' history.

In sharp contrast to these strong and almost identical quantitative scores in Metahistorical Concepts and the Past/Present (dis)Juncture domains, the programs differed significantly in the other two domains. Back in Time for Dinner had strong appeal to Popular Culture and Theatre with its use of filmic semiotics to develop the present-day characters thrown back in time. This created a vicarious experience for the viewers as they identified with trials and tribulations of the family. The dominance of the generalised historical narrative led to the neglect of History Disciplinary Practices which aligns with its more lighted-hearted approach to historical inquiry. This is reflected in its being awarded the lowest score of any domain, despite its strong use of artefacts and experts.

Antithetically, Who Do You Think You Are? scored highly in the Historical Disciplinary Practices domain indicating that the program used many of the methodologies of the historian to construct the stories, and that the narrative is fortified and verified by the use of evidence and experts. This explicit adherence to History Disciplinary Practices lends a solemnity to the program which contrasts with the use of the celebrity avatar. Despite the tensions created in the quest, this TV program scored less in the Popular Culture and Theatre domain, primarily due to the lack of simulation and re-enactment.

This promising model has the potential to be applied in a wide variety of other analytical contexts to investigate the repackaging of the past in the digital present. Further work with docudramas and other historical filmic representations, such as documentaries and feature films, will provide further verification of its validity and reliability as an analytical tool. Further research needs to be undertaken to apply this research design to other platforms beyond the filmic form. Such application will determine its transferability to other historical representations such as historical fiction in traditional and graphic form, real and virtual museum exhibitions, virtual reality and gaming experiences and commemorative rituals and traditions.

\section{Endnotes}

1. Paul Ashton and Paula Hamilton, History at the Crossroads: Australians and the Past, Halstead Press, Sydney, 2007, p29. 
U T S

e P R E S
2. Fenella Cannell, 'English ancestors: The moral possibilities of popular genealogy', Journal of the Royal Anthropological Institute, vol 17, pp462-480. https://doi.org/10.1111/j.1467-9655.2011.01702.x

3. Ashely Barnwell, 'The Genealogical Craze: Authoring and Authentic Identity through family history research', Life Writing, vol 10, no 3, 2013, pp261-275. https://doi.org/10.1080/14484528.2013.802198

4. Peter Seixas, 'Assessment of historical thinking', in Penney Clark (ed), New possibilities for the past: Shaping history education in Canada, University of British Columbia Press, Vancouver, Canada, 2011, pp139153.

5. Ashton and Hamilton, op cit, p115.

6. Landra Rezabek, 'Why Visual Literacy: Consciousness and Convention', Tech Trends, vol 49, no 3, 2005, pp19-20. https://doi.org/10.1007/bf02763642

7. Nielsen, 'Time Flies: US Adults Now Spend Nearly Half a Day Interacting with Media', July 312018 , viewed on September 5 2019, <www.nielsen.com/us/en/insights/article/2018/time-flies-us-adults-nowspend-nearly-half-a-day-interacting-with-media/>.

8. Robert A. Rosenstone, History on film/Film on history, Routledge, London, 2017, p65.

9. Robert B. Toplin, 'In Defense of the Filmmakers', in R. Francaviglia and J. Rodnitzky (eds), Lights, Camera, History: Portraying the Past in Film, Texas A7M University Press, College Station, 2007, pp113-135.

10. Robert A. Rosenstone, 'Confessions of a Postmodern Historian', in A. Munslow (ed), Authoring the Past: Writing and Rethinking History, Routledge, London, 2012, pp149-166.

11. Steven N. Lipkin, Docudrama Performs the Past: Arenas of Argument in Films Based on True Stories, Cambridge Scholars Publishing, London, 2011.

12. Vrinda Varnekar, Docudrama: Meaning, Characteristics and Examples updated February 26, 2018, viewed September 10 2019, <https://entertainism.com/docudrama-meaning-characteristics-examples>.

13. Cannell, op cit, $\mathrm{p} 466$.

14. Jose van Dijck, 'Mediated memories: personal cultural memory as object of cultural analysis', Continuum: Journal of Media and Cultural Studies, vol 18, no 2, 2004, pp261-277. https://doi. org/10.1080/1030431042000215040

15. The British original of Who Do You Think You Are? is now in its fifteenth season, and has a host of regional offshoots, including American, Australian, Canadian, Irish, South African, Israeli, Swedish, Norwegian, Danish, Dutch, Portuguese, Russian and Czech versions of the original program.

16. Jerome de Groot, Consuming History, Routledge, Oxford, 2009; Cannell, op cit; Anne-Marie Kramer, 'Kinship, affinity, and connectedness: Exploring the role of genealogy in personal lives', Sociology, vol 45, no 3, pp379-345. https://doi.org/10.1177/0038038511399622

17. Anne-Marie Kramer, 'Mediatizing memory: History, affect, and identity in Who Do You Think You Are?', European Journal of Cultural Studies, vol 14, no 428, 2011, pp428-445. https://doi. org/10.1177/1367549411404616

18. De Groot, op cit.

19. In Britain there is varied array of spin-offs of the original Back in Time for Dinner which first aired in 2015. These are testament to the enduring popularity in Britain of the format - Back in Time for the Weekend (2016), for Christmas (2015), for Brixton (2016), Further Back in Time for Dinner (2017), For Tea (2018), for the Factory (2018) for School (2019). Canadian version of Back in time for Dinner (2018).

20. Silvana K. Figueroa, 'The Grounded Theory and the Analysis of Audio-Visual Texts', International Journal of Social Research Methodology, vol 11, 2008, pp1-12. https://doi.org/10.1080/13645570701605897

21. Seixas, op cit. 